
C C只乨号
REPORT 76:24

\title{
CRREL
}

Vanadium and other elements in Greenland ice cores 
Cover: The 1973 GISP field camp at Milcent, Green-

land. (Photograph by C.C. Langway, Jr.) 


\section{CRREL Report 76-24}

\section{Vanadium and other elements in Greenland ice cores}

M.M. Herron, C.C. Langway, Jr., H.V. Weiss, J.P. Hurley, R.J. Kerr and J.H. Cragin

July 1976

Prepared for

NATIONAL SCIENCE FOUNDATION

By

CORPS OF ENGINEERS, U.S. ARMY

COLD REGIONS RESEARCH AND ENGINEERING LABORATORY

HANOVER, NEW HAMPSHIRE 
For conversion of SI metric units to U.S./British customary units of measurement consult ASTM Standard E380, Metric Practice Guide, published by the American Society for Testing and Materials, 1916 Race St., Philadelphia, Pa. 19103. 


\begin{tabular}{|c|c|}
\hline REPORT DOCUMENTATION PA & $\begin{array}{l}\text { READ INSTRUCTIONS } \\
\text { BEFORE COMPLETING FORM }\end{array}$ \\
\hline $\begin{array}{l}\text { 1. REPORT NUMBER } \\
\text { CRREL Report 76-24 }\end{array}$ & 3. RECIPIENT'S CATALOG NUMBER \\
\hline \multirow{2}{*}{$\begin{array}{l}\text { 4. TITLE (and Subtitie) } \\
\text { VANADIUM AND OTHER ELEMENTS IN GREENLAND } \\
\text { ICE CORES }\end{array}$} & 5. TYPE OF REPORT \& PERIOD COVERED \\
\hline & 6. PERFORMING ORG. REPORT NUMBER \\
\hline $\begin{array}{l}\text { 7. Au ThOR(s) } \\
\text { M.M. Herron, C.C. Langway, Jr., H.V. Weiss, J.P. Hurley, } \\
\text { R.J. Kerr and J.H. Cragin }\end{array}$ & $\begin{array}{l}\text { 8. CONTRACT OR GRANT NUMBER(s) } \\
\text { NSF Project OPP } 750-6750\end{array}$ \\
\hline $\begin{array}{l}\text { 9. PERFORMING ORGANIZATION NAME AND ADDRESS } \\
\text { U.S. Army Cold Regions Research and Engineering Laboratory } \\
\text { Hanover, New Hampshire } 03755\end{array}$ & $\begin{array}{l}\text { 10. PROGRAM ELEMENT, PROJECT, TASK } \\
\text { AREA \& WORK UNIT NUMBERS }\end{array}$ \\
\hline \multirow{2}{*}{$\begin{array}{l}\text { 11. CONTROLLING OFFICE NAME AND ADDRESS } \\
\text { Division of Polar Programs } \\
\text { National Science Foundation, Washington, D.C. }\end{array}$} & $\begin{array}{l}\text { 12. REPORT DATE } \\
\text { July } 1976\end{array}$ \\
\hline & $\begin{array}{l}\text { 13. NUMBER OF PAGES } \\
6\end{array}$ \\
\hline \multirow[t]{2}{*}{ 14. MONITORING AGENCY NAME \& ADDRESS(If different from Controlling Office) } & $\begin{array}{l}\text { 15. SECURITY CLASS. (of this report) } \\
\text { Unclassified }\end{array}$ \\
\hline & $\begin{array}{l}\text { 15a. DECLASSIFICATION/DOWNGRADING } \\
\text { SCHEDULE }\end{array}$ \\
\hline
\end{tabular}

16. DISTRIBUTION STATEMENT (of this Report)

Approved for public release; distribution unlimited.

17. DISTRIBUTION STATEMENT (of the abstract ontered in Block 20, if different from Report)

18. SUPPLEMENTARY NOTES

19. KEY WORDS (Continue on reverse side if necessary and identify by block number)

Annual accumulations Ice

Chemical analysis Ice cores

Dating Seasonal variations

Greenland Vanadium

20. ABSTRACT (Continue an reverse sidio if neceseary and identity by block number)

Chemical analysis of surface snows and deeper ice core samples from Milcent, Greenland, indicates a marine origin for $\mathrm{Na}$ and $\mathrm{Cl}$ and a terrestrial origin for $\mathrm{Al}, \mathrm{Mn}$ and $\mathrm{V}$. Pre-1900 enrichment factors, based on average crustal composition, are high for $\mathrm{Zn}$ and $\mathrm{Hg}$ and appear to be related to their volatility. A comparison of pre-1900 and 1971 1973 concentrations of $\mathrm{V}$ and $\mathrm{Hg}$ shows no decided increase from industrial production; however, the abundance of $\mathrm{Zn}$ (relative to $\mathrm{Al}$ ) increased three-fold during this time period. The chemical composition of ancient ice is extemely useful in interpreting modern aerosols. 


\section{PREFACE}

This report was prepared by M.M. Herron, graduate student in the Department of Chemistry, San Diego State University; by Dr. C.C. Langway, Jr., Chairman of the Department of Geological Sciences, State University of New York at Buffalo; by Dr. H.V. Weiss, Research Chemist, Dr. J.P. Hurley, Radiation Physicist, and R.J. Kerr, Physicist, of the Naval Undersea Center, San Diego, California, and by J.H. Cragin, Chemist, of the Snow and Ice Branch, Research Division, U.S. Army Cold Regions Research and Engineering Laboratory. The research was funded by the National Science Foundation's Division of Polar Programs Project OPP 750-6750.

Technical reviewers of the manuscript were Dr. I.K. Iskandar and D. Leggett of CRREL.

The authors gratefully thank E.D. Goldberg and M. Koide for laboratory use.

The contents of this report are not to be used for advertising, publication, or promotional purposes. Citation of trade names does not constitute an official endorsement or approval of the use of such commercial products. 


\section{VANADIUM AND OTHER ELEMENTS IN GREENLAND ICE CORES}

M.M. Herron, C.C. Langway, Jr., H.V. Weiss, J.P. Hurley, R.J. Kerr and J.H. Cragin

\section{INTRODUCTION}

The atmospheric concentrations of trace elements, particularly those which may include an anthropogenic fraction, have been the subject of much recent study (Zoller et al. 1973, Chester and Stoner 1974, Zoller et al. 1974, Duce et al. 1975). The crustal enrichment factor $E F$, used to identify possible pollutants; is defined as

$$
E F_{\mathrm{X}}=\frac{(X / \mathrm{Al})_{\text {SAMPLE }}}{(X / \mathrm{Al})_{\mathrm{CRUST}}}
$$

where $(X / \mathrm{Al})_{\text {SAMPLE }}$ and $(X / \mathrm{Al})_{\mathrm{CR} U S T}$ are the concentration ratios of the element $X$ to aluminum in the sample and in average crustal material, respectively. An element whose aerosol originates primarily from crustal weathering processes should have an $E F$ value near one. A significantly greater $E F$ indicates input from local or additional sources, selective volatilization at the source (Zoller et al. 1974), selective transport or selective deposition from the atmosphere.

One method of distinguishing naturally high enrichment factors from man's contribution to the atmospheric burden is the analysis of chemical impurities within ice cores from the Greenland ice sheet. Pollutant lead and sulfur have been identified in modern Greenland snows by comparison with concentrations in pre-1900 ice strata (Murozumi et al. 1969, Koide and Goldberg 1971, Weiss et al. 1974, Cragin et al. 1975). Mercury was identified as a possible pollutant in northern Greenland ice (Weiss et al. 1971a), though work in southern Greenland has disputed this (Weiss et al. 1975). Extreme variations in mercury concentrations in four northern Greenland samples were interpreted as suggesting that the natural mercury burden was highly variable (Carr and Wilkniss 1972).

This paper presents the results of a study designed to determine the elemental concentrations of $\mathrm{Na}, \mathrm{Cl}$, $\mathrm{Al}, \mathrm{Mn}, \mathrm{V}, \mathrm{Zn}$, and $\mathrm{Hg}$ in Greenland ice and snow over the past several hundred years, and to help determine the significance of modern aerosol analyses.

\section{SAMPLES}

During the 1973 field season of the Greenland Ice Sheet Program a field camp was established at Milcent $\left(70^{\circ} 18^{\prime} \mathrm{N}, 44^{\circ} 35^{\prime} \mathrm{W}\right)$. A continuous $400-\mathrm{m} \times 12-\mathrm{cm}-$ diam ice core was taken at the main camp and surface snow samples were collected at four pits 2 to $3 \mathrm{~km}$ from the camp (pit 1 was always upwind). The individual who collected the samples wore a cleanroom coat, surgical face mask, hair covering, and powderfree polyethylene gloves throughout the collection, and about $10 \mathrm{~cm}$ of snow was trimmed from the pit walls with a precleaned stainless steel shovel before the samples were taken. One-year channel samples, as determined by stratigraphic features, were obtained with a polyethylene scoop, placed in 10-liter polyethylene containers, bagged, and shipped while frozen to the U.S. All bottles and field implements were precleaned by leaching in $1 \% \mathrm{HNO}_{3}$, rinsing five times with distilled, deionized water $(D W)$, and rinsing twice with double-distilled, deionized water $(D D W)$. 
In the laboratory, the surface samples were melted in a microwave oven in their original 10 -liter containers and immediately transferred to hot nitric acid treated (HNAT) 1-liter linear polyethylene bottles. These bottles had been filled with reagent grade $\mathrm{HNO}_{3}$, heated to $80^{\circ}-90^{\circ} \mathrm{C}$ for periods greater than one hour, and rinsed five times with $D W$, twice with $D D W$ and twice with sample meltwater. This treatment was proven effective in preventing adsorption of ${ }^{48} \mathrm{~V}$ and ${ }^{203} \mathrm{Hg}$ for at least 32 days in separate 400 -ml aliquots of the pit 4 sample. The spike concentrations were $6.8 \mathrm{ng}{ }^{48} \mathrm{~V} / \mathrm{kg}$ (5400 counts per minute, $\left.\mathrm{cpm}\right)$ and $<1 \mathrm{ng}{ }^{203} \mathrm{Hg} / \mathrm{kg}(2400 \mathrm{cpm})$.

The ice core samples were cleaned by the "dry" cleaning procedure (Langway et al. 1974), which involves extensive rinsing of the core with $D D W$ in a Class 100 clean area. Three deep samples, not used for mercury concentration analysis, were stored in conventional 1-liter polyethylene bottles prepared by leaching with $7 \%$ Ultrex $\mathrm{HNO}_{3}$ for several days at room temperature, followed by the usual rinsing procedure. A concentration of $10 \mathrm{ng}{ }^{48} \mathrm{~V} / \mathrm{kg}$ was added to a 250 $\mathrm{ml}$ aliquot of the pit 4 sample in one of the 1-liter bottles and quantitatively recovered after 21 days storage.

Zinc concentrations were measured in the unconcentrated samples using flameless atomic absorption with stopped nitrogen flow during atomization. Eppendorf pipette tips used for sample injection were found to give erroneously high concentrations until they were given the hot nitric acid treatment. Mercury concentrations were measured in 1 -liter aliquots of the meltwater by neutron activation following the procedure of Williams et al. (1974). Before radiochemical $\mathrm{Hg}$ yields could be determined, the surface samples were destroyed in a laboratory fire and a yield of 0.9 was assumed. Aliquots containing $5 \mathrm{ml}$ of the same meltwater were analyzed for $\mathrm{Na}$ and $\mathrm{Cl}$ by instrumental neutron activation analysis (INAA).

The remainder of the samples, $600 \mathrm{ml}$ to 2 liters in volume, were evaporated to $20 \mathrm{ml}$ in a precleaned quartz flask in a clean air station. They were transferred to $50-\mathrm{ml}$ Teflon beakers in a glass enclosure under filtered $\mathrm{N}_{2}$, evaporated to $5 \mathrm{ml}$, and transferred to HNAT polyethylene irradiation vials (Weiss et al. 1971b). A spike of $0.2 \mathrm{ng}^{48} \mathrm{~V}$ added prior to the preconcentration was quantitatively recovered. The samples were then analyzed for $\mathrm{V}, \mathrm{Al}$, and $\mathrm{Mn}$ by INAA. All counting was done with a $75 \mathrm{~cm}^{2}$ Princeton Gamma-Tech $\mathrm{Ge}(\mathrm{Li})$ detector coupled to a Nuclear Data
Model 4420 computerized 4096 channel analyzer, and peaks were integrated by computer.

\section{RESULTS AND DISCUSSION}

The full data for Milcent snow and deeper ice are presented in Table I. Each ice core sample represents exactly two year's accumulation as determined by oxygen isotope ratios.*

The average chlorine to sodium ratio of the samples in Table $\mathrm{I}$ is 1.8, which matches the $\mathrm{Cl} / \mathrm{Na}$ ratio of bulk seawater and suggests a marine origin for these two elements. Based on average seawater composition, the contribution of sea spray to the other elements is minimal.

The mercury concentrations are the highest yet reported for Greenland snow and ice, and there is no indication of significant $\mathrm{Hg}$ input in modern times. One interpretation is that the hot nitric acid treatment of the linear polyethylene bottles prevented adsorption on the container walls and resulted in more representative concentrations. Sample contamination is not considered to be very likely since samples from Point Barrow, Alaska, which were processed and analyzed identically to the Milcent samples, showed consistently low concentrations. The storage containers for the study of Weiss et al. (1971a) were prepared using a cold nitric acid leaching (Murozumi et al. 1969), and the samples were stored unacidified for three years in liquid state prior to analysis for $\mathrm{Hg}$. In the study of Weiss et al. (1974) a cold acid leach was used and samples were analyzed 12 hours after melting (Weiss and Bertine 1973). Bottle preparation was not discussed by Carr and Wilkniss (1972).

Mean crustal enrichment factors using $\mathrm{Al}$ as the reference element are presented in Table II. The enrichment factors are calculated on the basis of the mean crustal abundance of Taylor (1964). Also given in Table II are enrichment factors for aerosol collections from Chester and Stoner (1974) for Atlantic Ocean "Westerlies" samples, from Duce et al. (1975) for Atlantic Ocean samples, and from Zoller et al. (1974) for South Pole aerosol samples.

\footnotetext{
* Personal communication, W. Dansgaard, University of Copenhagen.
} 
Table I. Elemental concentrations in Milcent snow and ice samples (all concentrations in $\mu \mathrm{g} / \mathrm{kg}$ ).

\begin{tabular}{cccccccccc} 
Sample & $\begin{array}{c}\text { Depth } \\
(\mathrm{m})\end{array}$ & Age & $\mathrm{Na}$ & $\mathrm{Cl}$ & $\mathrm{Al}$ & $\mathrm{V}$ & $\mathrm{Mn}$ & $\mathrm{Zn}$ & $\mathrm{Hg}$ \\
\hline Pit 1 & $0-1.36$ & $1972-3$ & 13 & 19 & 13 & 0.022 & 0.215 & 0.215 & $0.429^{*}$ \\
Pit 1 & $1.36-2.27$ & $1971-2$ & 15 & 25 & 7 & 0.018 & 0.097 & 0.248 & $0.370^{*}$ \\
Pit 1 & $1.52-2.75$ & $1971-2$ & 9 & 26 & 7 & 0.008 & 0.104 & 0.270 & $0.418^{*}$ \\
Pit 2 & $0-1.51$ & $1972-3$ & 11 & 24 & 6 & 0.021 & 0.125 & 0.211 & $0.290^{*}$ \\
Pit 3 & $0-1.37$ & $1972-3$ & 14 & 26 & 9 & 0.016 & 0.122 & & $0.578^{*}$ \\
Pit 4 & $0-1.38$ & $1972-3$ & 12 & 14 & 18 & 0.010 & 0.171 & 0.174 & $0.881^{*}$ \\
1588 & $109.94-111.10$ & $1803-5$ & 9 & 22 & 3 & $\mathrm{BD}+$ & 0.075 & 0.038 & \\
2757 & $169.43-170.42$ & $1687-9$ & 19 & 25 & 3 & $\mathrm{BD}+$ & 0.056 & 0.025 & \\
4467 & $250.09-251.00$ & $1600 * *$ & 14 & 23 & 7 & 0.019 & 0.051 & 0.070 & \\
1002 & $77.92-78.41$ & 1864 & & & & & & & 0.716 \\
1485 & $104.49-104.95$ & 1815 & & & & & & & 0.318 \\
2471 & $155.25-155.69$ & 1717 & & & & & & & 0.823 \\
2896 & $176.23-176.72$ & 1675 & & & & & & & 0.263 \\
3314 & $196.50-196.86$ & 1631 & & & & & & & \\
\hline
\end{tabular}

* Assumes radiochemical yield of 0.9 .

† Below detection limit of $0.007 \mu \mathrm{g} / \mathrm{kg}$.

** Estimated age.

Table II. Enrichment factors at Milcent, based on average crustal abundances of Taylor (1964).

\begin{tabular}{|c|c|c|c|c|c|}
\hline \multirow[b]{2}{*}{ Sample } & \multicolumn{5}{|c|}{ Enrichment factors } \\
\hline & $A I$ & $v$ & $M n$ & $Z n$ & $\mathrm{Hg}$ \\
\hline Avg 1600-1805 & 1.0 & $<1.8 \pm 0.1$ & $1.5 \pm 0.8$ & $12 \pm 3$ & $62,000 \pm 30,000 *$ \\
\hline Avg 1971-1973 & 1.0 & $1.1 \pm 0.6$ & $1.3 \pm 0.4$ & $32 \pm 15$ & $53,000 \pm 11,000$ \\
\hline South Pole $†$ & 1.0 & 1.4 & 1.4 & 69 & \\
\hline $\begin{array}{l}\text { Atlantic Ocean } \\
30^{\circ} \mathrm{N**}\end{array}$ & 1.0 & 17 & 2.6 & 110 & \\
\hline Atlantic Westerlies $† \dagger$ & 1.0 & 2.5 & 1.4 & 11 & \\
\hline
\end{tabular}

* Assumes average Al concentration of $8.5 \mu \mathrm{g} / \mathrm{kg}$ in the Milcent core.

† From Zoller et al. (1974).

** From Duce et al. (1975).

†† From Chester and Stoner (1974).

The crustal enrichment factors for $\mathrm{V}$ and $\mathrm{Mn}$ in Milcent ice are near unity and do not show any increase in modern deposits. This suggests a common origin due to crustal weathering. Duce et al. (1975) reported a vanadium $E F$ of 17 for aerosol samples collected at $30^{\circ} \mathrm{N}$ latitude over the Atlantic Ocean, attributable to the burning of $\mathrm{V}$-enriched fossil fuels. Zoller et al. (1974), on the other hand, found a vanadium EF of 1.4 for aerosol samples at the South Pole. The fact that fossil fuel-derived $V$ does not appear to reach the polar regions may be related to the relatively low volatility of $\mathrm{V}$ compounds.

The pre-1900 zinc $E F$ in Milcent ice is $12 \pm 3$, increasing to $32 \pm 15$ for $1971-1973$ snows. This indicates not only that zinc is selectively volatilized, transported to and/or precipitated in Greenland, but also that the atmospheric load of zinc has increased in 
modern times. The fossil fuel mobilization of $\mathrm{Zn}$ and $V$ has been estimated at 7 and $12 \times 10^{9} \mathrm{~g} /$ year, respectively (Bertine and Goldberg 1971). Yet the Milcent evidence suggests that industrial $\mathrm{Zn}$, and not $\mathrm{V}$, reaches the Greenland ice sheet.

\section{CONCLUSION}

At present, it appears that elemental enrichment factors in pre-1900 Greenland ice may be explained adequately in terms of crustal abundances and relative volatilities. Thus $\mathrm{Hg}$ and $\mathrm{Zn}$ have high $E F$ 's while those of $\mathrm{V}$ and $\mathrm{Mn}$ are near unity. Apparently the presence or absence of a pollution fraction in modern snows is also affected by relative volatilities. Efforts to expand the list of enrichment factors of ancient and modern precipitation are presently underway.

\section{LITERATURE CITED}

Bertine, K.K. and E.D. Goldberg (1971) Fossil fuel combustion and the major sedimentary cycle. Science, vol. 173, p. 233-5.

Carr, R.A. and P.E. Wilkniss (1972) Mercury in the Greenland ice sheet: Further data. Science, vol. 181, p. 843-4.

Chester, R. and J.H. Stoner (1974) The distribution of $\mathrm{Mn}, \mathrm{Fe}, \mathrm{Cu}, \mathrm{Ni}, \mathrm{Co}, \mathrm{Ga}, \mathrm{Cr}, \mathrm{V}, \mathrm{Ba}, \mathrm{Sr}, \mathrm{Sn}, \mathrm{Zn}$ and $\mathrm{Pb}$ in some soil-sized particulates from the lower troposphere over the world ocean. Marine Chemistry, vol. 2, p. 1273-85.

Cragin, J.H., M.M. Herron and C.C. Langway, Jr. (1975) The chemistry of 700 years of precipitation at Dye 3, Greenland. CRREL Research Report 341. AD A014970.

Duce, R.A., G.L. Hoffman and W.H. Zoller (1975) Atmospheric trace metals at remote northern and southern sites: pollution or natural? Science, vol. 187, p. 59-61.

Koide, M. and E.D. Goldberg (1971) Atmospheric sulfur and fossil fuel combustion. Journal of Geophysical Research, vol. 76, p. 7689-96.

Langway, C.C., Jr., M. Herron and J.H. Cragin (1974) Chemical profile of the Ross Ice Shelf at Little America V, Antarctica. Journal of Glaciology, vol. 13, p. 431-5.

Murozumi, M., T.J. Chow and C. Patterson (1969) Chemical concentrations of pollutant lead aerosols, terrestrial dusts and sea salts in Greenland and Antarctica snow strata. Geochimica et Cosmochimica Acta, vol. 33, p. 1247-94.
Taylor, S.R. (1964) Abundance of chemical elements in the continental crust: A new table. Geochimica et Cosmochimica Acta, vol. 28, p. 1273-85.

Weiss, H.V., M. Koide and E.D. Goldberg (1971a) Mercury in a Greenland Ice Sheet: Evidence of recent input by man. Science, vol. 174, p. 692-4.

Weiss, H.V., M. Koide and E.D. Goldberg (1971b) Selenium and sulfur in a Greenland Ice Sheet. Science, vol. 172, p. 261-3.

Weiss, H.V. and K.K. Bertine (1973) Simultaneous determination of manganese, copper, arsenic, cadmium, antimony, and mercury in glacial ice by radioactivation. Analytica Chimica Acta, vol. 65, p. 253-9.

Weiss, H.W., K.K. Bertine, M. Koide and E.D. Goldberg (1975) The chemical composition of a Greenland glacier. Geochimica et Cosmochimica Acta, vol. 39, p. 1-10.

Williams, P.M., K.J. Robertson, K. Chew and H.V. Weiss (1974) Mercury in the south polar seas and in the northeast Pacific Ocean. Marine Chemistry, vol. 2, p. 287-99.

Zoller, W.H., G.E. Gordon, E.S. Gladney and A.G. Jones (1973) The sources and distribution of vanadium in the atmosphere. Advances in Chemistry Series 123, American Chemical Society, Washington, D.C., p. 31-47.

Zoller, W.H., E.S. Gladney and R.A. Duce (1974) Atmospheric concentrations and sources of trace metals at the South Pole. Science, vol. 183, p. 198200. 